\title{
Analisis Kemandirian Anak Usia Dini Daviq Chairilsyah
}

\author{
Universitas Riau \\ email: daviqch@yahoo.com
}

\begin{abstract}
Abstrak
Aspek perilaku kemandirian pada anak tidak hanya untuk kehidupan anak usia dini pada saat ini saja, tetapi juga berdampak bagi masa depan anak ketika sudah dewasa. Oleh karena itu, perlu dilakukan pengukuran tingkat kemandirian anak sejak usia dini agar guru dapat mengetahui tingkat perkembangan kemandirian anak didiknya dan dapat melakukan kegiatan pembelajaran yang dapat memperbaiki dan meningkatkan kemandirian anak di sekolah. Jenis penelitian ini dilakukan dengan metode deskriptif kuantitatif untuk memperoleh gambaran kemandirian anak usia 5-6 tahun di TK Pertiwi Provinsi Riau dengan jumlah 7 indikator kemandirian anak usia dini. Subjek dalam penelitian ini adalah anak usia 5-6 tahun sebanyak 36 anak. Data yang diperoleh lalu dianalisis dengan menggunakan rumus persentase deskriptif. Berdasarkan hasil penelitian dan pembahasan yang dilakukan, peneliti dapat menyimpulkan bahwa secara umum kemandirian anak usia 5-6 tahun di TK Pertiwi Provinsi Riau berada dalam kategori mulai berkembang. Secara khusus, dilihat dari masing-masing indikator, diketahui bahwa kemandirian anak usia 5-6 tahun di TK Pertiwi Provinsi Riau diperoleh hasil sebagai berikut: 1) kemampuan fisik berada pada kriteria berkembang sesuai harapan, 2) percaya diri berada pada kriteria mulai berkembang, 3) bertanggung jawab berada pada kriteria mulai berkembang, 4) disiplin berada pada kriteria mulai berkembang, 5) pandai bergaul berada pada kriteria mulai berkembang, 6) saling berbagi berada pada kriteria mulai berkembang, 7) mengendalikan emosi berada pada kriteria mulai berkembang.
\end{abstract}

\section{Keywords: Kemandirian, Anak Usia Dini, Pengukuran.}

\begin{abstract}
The aspect of independence of behavior in children is not only for the lives of early childhood at this time, but also affects the future of children when they are adults. Therefore, it is necessary to measure the level of independence of children from an early age so that teachers can know the level of development of the independence of their students and can carry out learning activities that can improve and increase the independence of children in school. This type of research was conducted with quantitative descriptive methods to obtain a picture of the independence of children aged 5-6 years in TK Pertiwi Provinsi Riau with a total of 7 indicators of early childhood independence. Subjects in this study were children aged 5-6 years as many as 36 children. The data obtained is then analyzed using a descriptive percentage formula. Based on the results of research and discussion conducted, researchers can conclude that in general the independence of children aged 5-6 years in TK Pertiwi Provinsi Riau is in the category of developing. Specifically, seen from each indicator, it is known that the independence of children aged 5-6 years in TK Pertiwi Provinsi Riau obtained the following results: [1] physical ability is at the criteria of developing according to expectations, [2] selfconfidence is at the criteria starting to develop, [3] responsibility is in the criteria began
\end{abstract}


to develop, [4] discipline is in the criteria began to develop, [5] sociable is in the criteria began to develop, [6] sharing is in the criteria for developing, [7] controlling emotions is in the criteria for developing.

\section{Keywords: Independence, Early Childhood, Measurement}

\section{PENDAHULUAN}

Salah satu pendidikan moral utama yang harus ditanamkan pada anak sejak usia dini adalah kemandirian. Kemandirian penting untuk mulai ditanamkan dan dilakukan pada anak usia 5-6 tahun (Ardy, 2013). Hal ini penting untuk mejadi prioritas karena pada tahapan usia ini anak berada dalam masa keemasaan di mana anak sudah mulai mengembangkan berbagai kemampuan dan keterampilan dalam mengurus dirinya sendiri. Kemandirian menjadi penting bagi anak usia dini agar anak mampu menjalani kehidupan tanpa bergantung kepada orang lain. Mandiri dalam mempersiapkan diri anak untuk menjalani masa depan untuk membentuk anak menjadi pribadi yang berkualitas serta membuat anak mampu bergaul dengan orang lain. Anak mandiri cenderung lebih positif di dalam kehidupan kesehariannya, lebih banyak berprestasi di bidang akademik dan terlihat lebih percaya diri dalam menyelesaikan tugasnya sehari-hari (Dewi, 2014).

Anak usia dini berada pada rentang usia 0 sampai 6 tahun dan sedang mengalami proses tumbuh kembang yang bersifat unik. Pertumbuhan dan perkembangan dalam aspek agama dan moral, fisik- motorik, kognitif, sosial emosional, bahasa dan seni akan dijalani dalam setiap tahapan oleh anak. Anak usia dini akan mengalami pertumbuhan dan perkembangan yang berlangsung cepat sejak usia kelahirannya hingga usia enam tahun. Masa ini merupakan masa yang sangat strategis bagi perkembangan dalam aspek kemandirian di usia selanjutnya (Hewi, 2015).

Anak usia dini akan diberikan pembinaan dan rangsangan agar dapat mengalami perkembangan fundamental bagi kehidupan selanjutnya. Usia dini merupakan usia emas (golden age) dimana pada masa ini anak harus meningkatkan seluruh potensi yang harus dikembangkan. Anak memiliki karakteristik tertentu tidak sama dengan orang dewasa, rasa ingin tahu, antusias, dinamis dan selalu aktif terhadap apa yang dilihat, didengar, dirasakan, mereka selalu bereksplorasi dan belajar dalam kesehariannya (Illahi, 2016).

Salah satu tugas perkembangan anak untuk mencapai tahapan tersebut adalah menumbuhkan kemandirian. Mandiri atau sering juga disebut berdiri di atas kaki sendiri merupakan kemampuan seseorang untuk tidak bergantung pada orang lain serta bertanggung jawab atas apa yang dilakukannya (Rohmah, 2012). Desmita (2014) menyatakan bahwa mandiri adalah kemampuan untuk mengendalikan dan mengatur pikiran, perasaan, dan tindakan sendiri secara bebas serta berusaha untuk mengatasi perasaan-perasaan malu dan keraguraguan dalam kehidupan anak.

Usia dini adalah masa terbaik untuk mengembangkan potensi dan kemandirian anak usia dini. Perkembangan potensi dan kemandirian 
anak seharusnya dilakukan sejak dini, sehingga akan menumbuhkan kesiapan dalam menjalani dan mengikuti perkembangan zaman. Anak usia dini dapat menjadi pribadi mandiri, peran keluarga utamanya orang tua harus memperhatikan beberapa hal yang mempengaruhi kemandirian anak. Pola asuh orang tua kepada anak, hubungan anak dengan orang tua yang harmonis akan membentuk kemandirian anak usia dini. Akan tetapi, pada kenyataannya dalam kehidupan sehari-hari banyak orang tua yang belum mempersiapkan anak untuk belajar kemandirian sejak dini. Bahkan banyak orang tua berasumsi bahwa kemandirian anak akan terbentuk dengan sendirinya seiring pertambahan usia anak. Hasil penelitian terkini menunjukkan bahwa kemandirian anak akan terbentuk apabila anak sejak usia dini telah dipersiapkan dan diajarkan untuk belajar dalam melakukan hal-hal yang bisa dilakukan sendiri (Rahma, 2016).

Kemandirian merupakan aspek penting yang sebaiknya dimiliki setiap anak, karena berfungsi untuk membantu mencapai tujuan hidupnya sehingga akan sukses serta memperoleh penghargaan dan pencapaian yang positif di masa mendatang. Tanpa didukung sifat mandiri, anak akan sulit mencapai sesuatu secara maksimal. Kemandirian merupakan kemampuan untuk melepaskan diri dari ketergantungan terhadap orang lain dalam melakukan kegiatan atau tugas sehari-hari sendiri atau dengan sedikit bimbingan, sesuai dengan tahapan perkembangan dan kapasitasnya (Ali, 2016). Perkembangan kemandirian pada anak merupakan suatu proses yang terarah dan harus sejalan serta berlandaskan pada tujuan hidup manusia.
Anak usia 5-6 tahun sebaiknya sudah terlihat mandiri dalam mengerjakan tugas di sekolah yang menjadi tanggung jawabnya sendiri untuk dikerjakan sampai selesai. Namun, kenyataannya di sekolah banyak menunjukkan bahwa masih ada beberapa anak yang masih bergantung pada orang lain sehingga dapat dikatakan belum mandiri. Anak usia dini merupakan periode perkembangan dari bayi hingga 6 tahun yang terjadi dalam banyak aspek perkembangan dan memiliki potensi yang masih harus dikembangkan. Tujuannya adalah agar kelak anak dapat tumbuh dan berkembang sesuai dengan harapan, yaitu anak yang cerdas, kreatif, inovatif dan bertaqwa, karena masa usia dini adalah masa yang sangat menentukan masa depan anak (Rohmah, 2012).

Tujuan umum dari penelitian ini adalah untuk mengetahui kemandirian anak usia 5-6 tahun di TK Pertiwi Provinsi Riau. Sedangkan tujuan khusus penelitian ini untuk mengetahui kemandirian anak usia 5-6 tahun pada indikator kemampuan fisik, rasa percaya diri, bertanggung jawab, disiplin, pandai bergaul, saling berbagi dan mengendalikan emosi.

\section{METODE}

\section{Rancangan Penelitian}

Jenis penelitian ini adalah penelitian deskriptif. Tujuan utama penelitian deskriptif adalah untuk memberikan gambaran secara sistematis tentang keadaan yang sedang berlangsung pada objek/subjek penelitian. Pendekatan yang digunakan dalam penelitian ini adalah penelitian kuantitatif (menggambarkan hasil penelitian 
berdasarkan angka dan jumlah) (Sugiyono, 2013).

\section{Populasi dan Sampel}

Populasi penelitian ini adalah 59 anak usia 5-6 tahun di TK Pertiwi Provinsi Riau. Sampel penelitian yang digunakan adalah anak usia 5-6 tahun di TK Pertiwi Provinsi Riau yang terdiri dari 36 anak. Teknik pengambilan sampel yang digunakan adalah simple random sampling yakni pengambilan secara acak tanpa memperhatikan strata yang ada dalam populasi tersebut, cara demikian dapat dilakukan apabila anggota populasi dianggap homogen (Sugiyono, 2013).

\section{Data dan Instrumen Penelitian}

Data yang digunakan dalam penelitian ini merupakan data primer yaitu data yang diperoleh langsung dari responden yang diteliti. Instrumen yang digunakan adalah berbentuk lembaran observasi. Lembaran observasi yang dipergunakan oleh peneliti untuk melihat bagaimana tingkat kemandirian anak Lembar observasi yang digunakan dalam penelitian ini menggunakan indikatorindikator kemandirian yang diadopsi dari Martinis (2013). Adapun instrumennya sebagai berikut:

Tabel 1. Instrumen Observasi Kemandirian

\begin{tabular}{cccc}
\hline No & Indikator & \multicolumn{2}{c}{ Sub Indikator } \\
\hline 1 & $\begin{array}{l}\text { Kemampuan } \\
\text { Fisik }\end{array}$ & $\begin{array}{l}\text { a. Anak mampu melepas } \\
\text { dan memakai sepatu } \\
\text { sendiri. }\end{array}$ \\
& & $\begin{array}{l}\text { b. Anak mampu makan } \\
\text { bekal sendiri. }\end{array}$ \\
\hline
\end{tabular}

\begin{tabular}{|c|c|c|}
\hline \multirow[t]{2}{*}{2} & \multirow[t]{2}{*}{ Percaya diri } & $\begin{array}{l}\text { a. Anak berani tampil di } \\
\text { depan kelas. }\end{array}$ \\
\hline & & $\begin{array}{lr}\text { b. Anak } & \text { mampu } \\
\text { mengerjakan } & \text { tugas } \\
\text { sendiri. } & \end{array}$ \\
\hline \multirow[t]{2}{*}{3} & $\begin{array}{l}\text { Bertanggung } \\
\text { jawab }\end{array}$ & $\begin{array}{lr}\text { a. Anak } & \text { mampu } \\
\text { merapikan } & \text { mainannya } \\
\text { sendiri. } & \end{array}$ \\
\hline & & $\begin{array}{l}\text { b. Anak } \\
\text { merapikan } \\
\text { sendiri. }\end{array}$ \\
\hline \multirow[t]{2}{*}{4} & Disiplin & $\begin{array}{l}\text { a. Anak datang ke sekolah } \\
\text { tepat waktu. }\end{array}$ \\
\hline & & $\begin{array}{l}\text { b. Anak mampu } \\
\text { meletakkan sepatu ke } \\
\text { dalam rak. }\end{array}$ \\
\hline \multirow[t]{2}{*}{5} & $\begin{array}{l}\text { Pandai } \\
\text { bergaul }\end{array}$ & $\begin{array}{l}\text { a. Anak tidak } \\
\text { mengganggu temannya } \\
\text { saat bermain. }\end{array}$ \\
\hline & & $\begin{array}{l}\text { b. Anak senang } \\
\text { membantu temannya. }\end{array}$ \\
\hline \multirow[t]{2}{*}{6} & $\begin{array}{l}\text { Saling } \\
\text { berbagi }\end{array}$ & $\begin{array}{ll}\text { a. Anak senang } & \text { berbagi } \\
\text { makanan } & \text { dengan } \\
\text { temannya. } & \end{array}$ \\
\hline & & $\begin{array}{l}\text { b. Anak mau } \\
\text { meminjamkan alat tulis } \\
\text { dengan temannya. }\end{array}$ \\
\hline \multirow[t]{2}{*}{7} & $\begin{array}{l}\text { Mengendalik } \\
\text { an emosi }\end{array}$ & $\begin{array}{l}\text { a. Anak tidak menangis } \\
\text { ketika ditinggal orang } \\
\text { tua di sekolah. }\end{array}$ \\
\hline & & $\begin{array}{l}\text { b. Anak } \\
\text { mengantri } \\
\text { tangan. }\end{array}$ \\
\hline
\end{tabular}

Sumber: Martinis (2013)

Kriteria penilaian:

BB (Belum Berkembang)

MB (Mulai Berkembang)

BSH (Berkembang Sesuai Harapan)

BSB (Berkembang Sangat Baik)

Teknik pengumpulan data yang digunakan peneliti dalam penelitian ini adalah lembar observasi. Teknik analisis 
data dalam penelitian ini menggunakan rumus persentase dengan formula sebagai berikut:

$$
\mathrm{P}=\frac{F}{\mathrm{~N}} \times 100 \%
$$

\section{HASIL DAN PEMBAHASAN}

\section{Hasil}

\section{Hasil perhitungan data kemandirian anak di TK Pertiwi Provinsi Riau}

Pengukuran terhadap kemandirian anak usia 5-6 tahun di TK Pertiwi Provinsi Riau dapat dilihat dari tabel di bawah ini:

Tabel 2. Data kemandirian anak usia 56 tahun di TK Pertiwi Provinsi Riau

\begin{tabular}{|c|c|c|c|c|}
\hline No & Indikator & $\begin{array}{l}\text { Rata } \\
\text {-rata }\end{array}$ & $\begin{array}{l}\text { Persen } \\
\text { tase } \\
(\%)\end{array}$ & $\begin{array}{l}\text { Krite } \\
\text { ria }\end{array}$ \\
\hline 1 & $\begin{array}{l}\text { Kemamp } \\
\text { uan Fisik }\end{array}$ & 4,16 & $\begin{array}{c}52,07 \\
\%\end{array}$ & $\mathrm{BSH}$ \\
\hline 2 & $\begin{array}{l}\text { Percaya } \\
\text { Diri }\end{array}$ & 3,87 & $\begin{array}{c}48,60 \\
\%\end{array}$ & $\mathrm{MB}$ \\
\hline 3 & $\begin{array}{l}\text { Bertangg } \\
\text { ung } \\
\text { Jawab }\end{array}$ & 3,80 & $\begin{array}{c}47,55 \\
\%\end{array}$ & MB \\
\hline 4 & Disiplin & 3,76 & $46,7 \%$ & MB \\
\hline 5 & $\begin{array}{l}\text { Pandai } \\
\text { Bergaul }\end{array}$ & 3,75 & $\begin{array}{c}47,21 \\
\%\end{array}$ & $\mathrm{MB}$ \\
\hline 6 & $\begin{array}{l}\text { Saling } \\
\text { Berbagi }\end{array}$ & 3,80 & $\begin{array}{c}47,55 \\
\%\end{array}$ & MB \\
\hline 7 & $\begin{array}{l}\text { Mengend } \\
\text { alikan } \\
\text { Emosi }\end{array}$ & 3,68 & $\begin{array}{c}46,17 \\
\%\end{array}$ & $\mathrm{MB}$ \\
\hline & Jumlah & 3,83 & $\begin{array}{c}48,01 \\
\%\end{array}$ & $\mathrm{MB}$ \\
\hline
\end{tabular}

Dari tabel di atas menunjukkan jumlah skor masing-masing indikator dari kemandirian, dimana secara deskriptif dapat ditunjukkan bahwa nilai (skor) dari analisis kemandirian anak usia 5-6 tahun di TK Pertiwi Provinsi Riau sebanyak 36 anak dengan 7 indikator diantaranya kemampuan fisik, percaya diri, bertanggung jawab, disiplin, pandai bergaul, saling berbagi, dan mengendalikan emosi dengan persentase $48,01 \%$ dengan kriteria MB (Mulai Berkembang).

Hasil perhitungan skor data kemandirian anak usia 5-6 tahun di TK Pertiwi Provinsi Riau ditinjau dari 7 indikator:

\section{Indikator Kemampuan Fisik}

Data kemandirian anak usia 5-6 tahun di TK Pertiwi Provinsi Riau dari indikator kemampuan fisik dapat dilihat pada tabel di bawah ini.

Tabel 3. Data kemandirian dari indikator kemampuan fisik

\begin{tabular}{ccccc}
\hline Sub & Skor & Skor & Persen & \\
Indikator & Faktual & Ideal & $\begin{array}{c}\text { tase } \\
(\%)\end{array}$ & Kriteria \\
& & & &
\end{tabular}

\begin{tabular}{|c|c|c|c|c|}
\hline $\begin{array}{l}\text { Anak } \\
\text { mampu } \\
\text { melepas } \\
\text { dan } \\
\text { memaka } \\
\text { i sepatu } \\
\text { sendiri }\end{array}$ & 74 & 144 & 52,08 & $\mathrm{BSH}$ \\
\hline $\begin{array}{l}\text { Anak } \\
\text { mampu } \\
\text { makan } \\
\text { makanan } \\
\text { sendiri }\end{array}$ & 74 & 144 & 52,08 & $\mathrm{BSH}$ \\
\hline
\end{tabular}




$\begin{array}{lllll}\text { Total } & 148 & 288 & 52,08 & \text { BSH }\end{array}$

Dari tabel di atas dapat dijelaskan bawa kemandirian anak usia 5-6 tahun di TK Pertiwi Provinsi Riau dilihat dari indikator kemampuan fisik dengan persentase $52,08 \%$ berada pada kriteria BSH (Berkembang Sesuai Harapan).

\section{Indikator Percaya Diri}

Data kemandirian anak usia 5-6 tahun di TK Pertiwi Provinsi Riau dari indikator percaya diri dapat dilihat pada tabel di bawah ini.

Tabel 4. Data kemandirian indikator percaya diri

\begin{tabular}{ccccc}
\hline Sub & Skor & Sk & Persen & Kate \\
Indikator & Fakt & or & tase & Ide \\
& ual & al & $(\%)$ & gori \\
& & & &
\end{tabular}

\begin{tabular}{|c|c|c|c|c|}
\hline $\begin{array}{l}\text { Anak } \\
\text { berani } \\
\text { tampil } \\
\text { di depan } \\
\text { kelas }\end{array}$ & 68 & $\begin{array}{c}14 \\
4\end{array}$ & 47,91 & $\mathrm{MB}$ \\
\hline $\begin{array}{l}\text { Anak } \\
\text { mampu } \\
\text { mengerj } \\
\text { akan } \\
\text { tugas } \\
\text { sendiri }\end{array}$ & 72 & $\begin{array}{c}14 \\
4\end{array}$ & 49,30 & $\mathrm{MB}$ \\
\hline Total & 140 & $\begin{array}{c}28 \\
8\end{array}$ & 48,61 & $\mathrm{MB}$ \\
\hline
\end{tabular}

Dari tabel di atas dapat dijelaskan bawa kemandirian anak usia 5-6 tahun di TK Pertiwi Provinsi Riau dilihat dari indikator percaya diri dengan persentase 48,61\% berada pada kriteria MB (Mulai Berkembang).

\section{Indikator Bertanggung Jawab}

Data kemandirian anak usia 5-6 tahun di TK Pertiwi Provinsi Riau dari indikator bertanggung jawab dapat dilihat pada tabel di bawah ini.

Tabel 5. Data kemandirian indikator bertanggung jawab

\begin{tabular}{ccccc}
\hline Sub & Skor & Sk & Persent & Kateg \\
Indikat & Fakt & or & ase & ori \\
or & ual & Ide & $(\%)$ & \\
& & al & &
\end{tabular}

\begin{tabular}{|c|c|c|c|c|}
\hline $\begin{array}{l}\text { Anak } \\
\text { mampu } \\
\text { merapi } \\
\text { kan } \\
\text { mainan } \\
\text { nya } \\
\text { sendiri }\end{array}$ & 67 & $\begin{array}{c}14 \\
4\end{array}$ & 47,22 & MB \\
\hline $\begin{array}{l}\text { Anak } \\
\text { mampu } \\
\text { merapi } \\
\text { kan } \\
\text { buku } \\
\text { sendiri }\end{array}$ & 70 & $\begin{array}{c}14 \\
4\end{array}$ & 47,91 & MB \\
\hline Total & 137 & $\begin{array}{c}28 \\
8\end{array}$ & 47,56 & MB \\
\hline
\end{tabular}

Dari tabel di atas dapat dijelaskan bawa kemandirian anak usia 5-6 tahun di TK Pertiwi Provinsi Riau dilihat dari indikator bertanggung jawab dengan persentase $47,56 \%$ berada pada kriteria MB (Mulai Berkembang). 


\section{Indikator Disiplin}

Data kemandirian anak usia 5-6 tahun di TK Pertiwi Provinsi Riau dari indikator disiplin dapat dilihat pada tabel di bawah ini.

Tabel 6. Data kemandirian indikator disiplin

\begin{tabular}{ccccc}
\hline Sub & Skor & Sk & Persent & Kateg \\
Indikato & Fakt & or & ase & Ide \\
r & ual & al & $(\%)$ & ori \\
& & & &
\end{tabular}

\begin{tabular}{|c|c|c|c|c|}
\hline $\begin{array}{l}\text { Anak } \\
\text { datang } \\
\text { ke } \\
\text { sekolah } \\
\text { tepat } \\
\text { waktu }\end{array}$ & 71 & $\begin{array}{c}14 \\
4\end{array}$ & 48,61 & $\mathrm{MB}$ \\
\hline $\begin{array}{l}\text { Anak } \\
\text { mampu } \\
\text { meleta } \\
\text { kkan } \\
\text { sepatu } \\
\text { ke } \\
\text { dalam } \\
\text { rak }\end{array}$ & 64 & $\begin{array}{c}14 \\
4\end{array}$ & 45,13 & MB \\
\hline Total & 135 & $\begin{array}{c}28 \\
8\end{array}$ & 46,87 & MB \\
\hline
\end{tabular}

Dari tabel di atas dapat dijelaskan bawa kemandirian anak usia 5-6 tahun di TK Pertiwi Provinsi Riau dilihat dari indikator disiplin dengan persentase 46,87\% berada pada kriteria MB (Mulai Berkembang).

\section{Indikator Pandai Bergaul}

Data kemandirian anak usia 5-6 tahun di TK Pertiwi Provinsi Riau dari indikator pandai bergaul dapat dilihat pada tabel di bawah ini.
Tabel 7. Data kemandirian indikator pandai bergaul

\begin{tabular}{|c|c|c|c|c|}
\hline $\begin{array}{c}\text { Sub } \\
\text { Indikato } \\
r\end{array}$ & $\begin{array}{c}\text { Skor } \\
\text { Fakt } \\
\text { ual }\end{array}$ & $\begin{array}{c}\text { Sk } \\
\text { or } \\
\text { Ide } \\
\text { al }\end{array}$ & $\begin{array}{l}\text { Persen } \\
\text { tase } \\
(\%)\end{array}$ & $\begin{array}{c}\text { Kateg } \\
\text { ori }\end{array}$ \\
\hline
\end{tabular}

\begin{tabular}{|c|c|c|c|c|}
\hline $\begin{array}{l}\text { Anak } \\
\text { tidak } \\
\text { mengga } \\
\text { nggu } \\
\text { temanny } \\
\text { a saat } \\
\text { bermain }\end{array}$ & 67 & $\begin{array}{l}14 \\
4\end{array}$ & 47,22 & MB \\
\hline $\begin{array}{l}\text { Anak } \\
\text { senang } \\
\text { memban } \\
\text { tu } \\
\text { temanny } \\
\text { a }\end{array}$ & 67 & $\begin{array}{l}14 \\
4\end{array}$ & 47,22 & MB \\
\hline Total & 134 & $\begin{array}{c}28 \\
8\end{array}$ & 47,22 & MB \\
\hline
\end{tabular}

Dari tabel di atas dapat dijelaskan bawa kemandirian anak usia 5-6 tahun di TK Pertiwi Provinsi Riau dilihat dari indikator pandai bergaul dengan persentase $47,22 \%$ berada pada kriteria MB (Mulai Berkembang).

\section{Indikator Saling Berbagi}

Data kemandirian anak usia 5-6 tahun di TK Pertiwi Provinsi Riau dari indikator saling berbagi dapat dilihat pada tabel di bawah ini:

Tabel 8. Data kemandirian indikator saling berbagi

\begin{tabular}{ccccc}
\hline $\begin{array}{c}\text { Sub } \\
\text { Indikator }\end{array}$ & $\begin{array}{c}\text { Skor } \\
\text { Fakt } \\
\text { ual }\end{array}$ & $\begin{array}{c}\text { Skor } \\
\text { Ideal }\end{array}$ & $\begin{array}{c}\text { Persen } \\
\text { tase } \\
(\%)\end{array}$ & $\begin{array}{c}\text { Kateg } \\
\text { ori }\end{array}$ \\
\hline $\begin{array}{l}\text { Anak } \\
\text { senang }\end{array}$ & 66 & 144 & 46,52 & MB \\
\hline
\end{tabular}




\begin{tabular}{|c|c|c|c|c|}
\hline $\begin{array}{l}\text { berbagi } \\
\text { makana } \\
\mathrm{n} \text { dengan } \\
\text { temanny } \\
\text { a }\end{array}$ & & & & \\
\hline $\begin{array}{l}\text { Anak } \\
\text { mau } \\
\text { meminja } \\
\text { mkan } \\
\text { alat tulis } \\
\text { dengan } \\
\text { temanny } \\
\text { a }\end{array}$ & 71 & 144 & 48,61 & MB \\
\hline Total & 137 & 288 & 47,56 & MB \\
\hline
\end{tabular}

Dari tabel di atas dapat dijelaskan bawa kemandirian anak usia 5-6 tahun di TK Pertiwi Provinsi Riau dilihat dari indikator saling berbagi dengan persentase $47,56 \%$ berada pada kriteria MB (Mulai Berkembang).

\section{Indikator Mengendalikan Emosi}

Data kemandirian anak usia 5-6 tahun di TK Pertiwi Provinsi Riau dari indikator saling berbagi dapat dilihat pada tabel di bawah ini.

Tabel 9. Data kemandirian indikator mengendalikan emosi

\begin{tabular}{lllll}
\hline Sub & Skor & Skor & Perse & \\
Indikator & Faktu & Ideal & ntase & Kategori \\
& al & & $(\%)$ & \\
& & & &
\end{tabular}

\begin{tabular}{|c|c|c|c|c|}
\hline $\begin{array}{l}\text { Anak } \\
\text { tidak } \\
\text { menangis } \\
\text { ketika } \\
\text { ditinggal } \\
\text { orang tua } \\
\text { di sekolah }\end{array}$ & 68 & 144 & 47,91 & $\mathrm{MB}$ \\
\hline $\begin{array}{l}\text { Anak } \\
\text { mampu } \\
\text { mengantr }\end{array}$ & 65 & 144 & 44,44 & $\mathrm{MB}$ \\
\hline
\end{tabular}

i mencuci

tangan

$\begin{array}{lllll}\text { Total } & 133 & 288 & 46,18 & \text { MB }\end{array}$

Dari tabel di atas dapat dijelaskan bahwa kemandirian anak usia 5-6 tahun di TK Pertiwi Provinsi Riau dilihat dari indikator saling berbagi dengan persentase $46,18 \%$ berada pada kategori kriteria MB (Mulai Berkembang).

\section{Pembahasan}

Kemandirian anak dibentuk dari lingkungan keluarga dimana anak tinggal dan dari kesempatan yang diberikan orang tua kepada anaknya untuk melakukan sesuatu secara mandiri. Berdasarkan hasil analisis dan pengolahan data diperoleh persentase keseluruhan indikator hasil analisis kemandirian anak usia 5-6 tahun di TK Pertiwi Provinsi Riau dari hasil pengumpulan data diperoleh skor bahwa kemandirian anak usia 5-6 tahun di TK Pertiwi Provinsi Riau berada dalam kriteria (Mulai Berkembang).

Hasil analisis data kemandirian anak usia 5-6 tahun di TK Pertiwi Provinsi Riau dilihat dari indikator kemampuan fisik berada pada kriteria Berkembang Sesuai Harapan. Kemandirian anak didik dalam kegiatan mencuci tangan, makan, memakai pakaian, mandi atau buang air kecil atau besar sendiri sudah sesuai dengan harapan.

Hasil analisis data kemandirian anak usia dini 5-6 tahun di TK Pertiwi Provinsi Riau dilihat dari indikator percaya diri berada pada kriteria Mulai Berkembang. Menurut Zimmerman (Susanto, 2017) bahwa anak yang mandiri itu adalah anak yang 
mempunyai kepercayaan diri yang tinggi. Zimmerman yakin bahwa kepercayaan diri tersebut merupakan kunci utama bagi kemandirian anak. Dengan kepercayaan dirinya, anak berani tampil dan berekspresi didepan orang banyak atau didepan umum.

Hasil analisis data kemandirian anak usia dini 5-6 tahun di TK Pertiwi Provinsi Riau dilihat dari indikator bertanggung jawab berada pada kriteria Mulai Berkembang. Mandiri atau sering berdiri sendiri di atas kaki sendiri, merupakan kemampuan seseorang untuk tidak bergantung pada orang lain serta bertanggung jawab atas apa yang dilakukannya (Fatimah, 2006). Apabila lingkungan sekitar mendukung maka akan terbentuk pribadi yang mandiri, mampu mengambil keputusan dan bertanggung jawab dalam melakukan berbagai tindakan yang telah dilakukan.

Hasil analisis data kemandirian anak usia dini 5-6 tahun di TK Pertiwi Provinsi Riau dilihat dari indikator disiplin berada pada kriteria Mulai Berkembang. Pembelajaran disiplin diri pada anak usia dini mutlak diperlukan dalam rangka untuk membentuk anak menjadi pribadi yang teratur dan patuh pada peraturan di rumah dan di sekolah.

Hasil analisis data kemandirian anak usia dini 5-6 tahun di TK Pertiwi Provinsi Riau dilihat dari indikator pandai bergaul berada pada kriteria Mulai Berkembang. Menurut Brewer (Martinis, 2013) pandai bergaul termasuk ke dalam perkembangan sosial emosi meliputi pemahaman terhadap diri sendiri dan berhubungan dengan orang lain yaitu teman sebaya dan orang dewasa. Dalam hal ini kemampuan anakanak didik sudah mulai menunjukkan sikap untuk mau memulai suatu relasi sosial yang sederhana karena anak usia dini masih polos dan terkesan takut pada situasi yang baru dikenalnya.

Hasil analisis data kemandirian anak usia dini 5-6 tahun di TK Pertiwi Provinsi Riau dilihat dari indikator saling berbagi berada pada kriteria Mulai Berkembang. Menurut Martinis (2013) kemandirian anak ditinjau dari segi saling berbagi dapat dilihat dalam bekerjasama. Dalam kehidupan sekolah, anak tidak hanya sendiri melainkan terdapat teman-teman lain yang seusianya. Guru harus memiliki cara untuk membuat anak meningkatkan kemandiriannya dengan cara membiarkan anak membentuk kelompok dan bekerja dalam kelompok.

Hasil analisis data kemandirian anak usia dini 5-6 tahun di TK Pertiwi Provinsi Riau dilihat dari indikator mengendalikan emosi berada pada kriteria Mulai Berkembang. Kemandirian pada seorang anak dapat dilihat dari kegiatan anak sehari-hari yang terwujud pada perilaku emosinya dalam kehidupan sosialnya. Kemampuan anak-anak sudah muali berkembang, namun perlu dapat ditingkatkan lagi agar anak dapat bersabar dalam mennghadapi tugas yang dibebankan guru, sabar dalam berteman dan sabar dalam mengikuti aturan di sekolah.

Adapun beberapa upaya yang dapat dilakukan dalam mengembangkan kemandirian anak ini, sebagaimana yang disarankan oleh Ratri Sunar Astuti (Susanto, 2017) yaitu, anak-anak didorong agar mau melakukan sendiri kegiatan sehari-hari-hari, anak diberi kesempatan sesekali mengambil keputusan sendiri, diberi kesempatan untuk bermain sendiri tanpa ditemani sehingga terlatih untuk mengembangkan ide dan berpikir untuk dirinya, dan melatih anak untu mensosialisasikan diri 
sehingga anak belajar menghadapi problem sosial yang lebih kompleks.

Jadi dapat disimpulkan bahwa kemandirian merupakan suatu kekuatan internal yang diperoleh melalui proses realisasi kemandirian dan proses menuju kesempurnaan, sehingga sikap mandiri ini penting dimiiki oleh setiap individu. Orang tua dan guru mempunyai peranan yang sangat penting dalam membentuk kemandirian pada diri anak usia dini.

\section{KESIMPULAN}

Berdasarkan hasil penelitian dan pembahasan yang dilakukan, peneliti dapat menyimpulkan bahwa secara umum kemandirian anak usia 5-6 tahun di TK Pertiwi Provinsi Riau berada dalam kategori mulai berkembang. Secara khusus, dilihat dari masingmasing indikator, diketahui bahwa kemandirian anak usia 5-6 tahun di TK Pertiwi Provinsi Riau diperoleh hasil sebagai berikut: 1) kemampuan fisik berada pada kriteria berkembang sesuai harapan, 2) percaya diri berada pada kriteria mulai berkembang, 3) bertanggung jawab berada pada kriteria mulai berkembang, 4) disiplin berada pada kriteria mulai berkembang, 5) pandai bergaul berada pada kriteria mulai berkembang, 6) saling berbagi berada pada kriteria mulai berkembang, 7) mengendalikan emosi berada pada kriteria mulai berkembang.

\section{DAFTAR PUSTAKA}

[1] Ali, Mohammad dan Asrori, Mohammad. 2016. Psikologi Remaja Perkembangan Peserta Didik. Jakarta: Bumi Aksara.

[2] Ardy, Wiyani Novan. 2013. Bina Karakter Anak Usia Dini. Yogjakarta: Ar-ruzz Media.
[3] Desmita. 2014. Psikologi Perkembangan Peserta Didik. Bandung: Remaja Rosdakarya.

[4] Dewi, Citra,. Asrori, M., dan Yuline. 2014. Analisis Pembelajaran dalam Mengembangkan Kemandirian Pada Anak Usia 5-6 Tahun di TK Pertiwi 1 Pontianak. Jurnal Pendidikan dan Pembelajaran: 3 (10).

[5] Fatimah, Enung. 2006. Psikologi Perkembangan. Bandung: CV Pustaka Setia.

[6] Hewi, La. 2015. Kemandirian Usia Dini di Suku Bajo. Jurnal Pendidikan Usia Dini: 9 (1): 7681.

[7] Illahi, Sri Rahayu. 2016. Analisis Kemandirian Anak Usia 5-6 Tahun di PAUD Bhakti Bunda Kecamatan Payung Sekaki Kota Pekanbaru. Universitas Riau.

[8] Martinis, Yamin dan Sannan, Jamilah Sabri. 2013. Panduan Pendidikan Anak Usia Dini. Jakarta: GP Press.

[9] Rahma, Siti., Utami, Dwi Ade dan Hapidin. 2016. Kemandirian Anak Usia 5-6 Tahun di Komunitas Lingkungan Pemulung. Jurnal Ilmiah VISI PPTK PAUDNI: 11(1).

[10] Rohmah, Tuti. 2012. Meningkatkan Kemandirian Anak Melalui Kegiatan Practical Life Kelompok-A di Ra Al-Ikhlas Medokan Ayu Rungkut Surabaya. Surabaya: UNESA.

[11] Sugiyono. 2013. Metode Penelitian Kuantitatif, Kualitatif, $R \& D$. Bandung: Alfabeta.

[12] Sugiyono. 2013. Metode Penelitian Pendidikan Pendekatan Kuantitatif, Kualitatif, dan $R \& D$. Bandung: Alfabeta. 
[13] Sugiyono. 2013. Statistika untuk Penelitian. Bandung: Alfabeta.

[14] Sukardi. 2012. Metodologi Penelitian Pendidikan Kompetensi dan Praktiknya. Jakarta: Bumi Aksara.

[15] Susanto, Ahmad. 2017. Pendidikan Anak Usia Dini (Konsep dan Teori). Jakarta: Bumi Aksara. 